\title{
K121001
}

\section{グローバル化する企業の技術課題と 設計の体系化あるいは教育の可能性について}

\section{Technology Problems at Globalized Enterprise \\ and Feasibility of Design Systematization or Design Learning}

\author{
Hiroyuki ITOH
}

Daikin Industries, Ltd. Technology and Innovation Center Development Dept. 1304 Kanaoka-cho, Kita-ku, Sakai-shi, Osaka, 591-8511 Japan

\begin{abstract}
Most of Japanese manufacturers are confronted with being globalized corresponding to various demands such as enlargement of market and acquisition of management resources. However, different scheme of technology transfer and integration in almost every layer and process is required against the background of "Merger \& Acquisition Era" as a result of liberalization of international capital transfer. In the speech, technological problems in the design process under consideration of maintenance and enhancement of the brand are shown, and feasibility of Design Systematization and Design Leaning centered in Project Based Learning, for the purpose of establishment of methodologies which dissolve the internal competition and create the new values, is examined.
\end{abstract}

Key Words : Globalized Enterprise, Design Systematization, Design Learning

\section{1. 蝡}

日本の製造業は，マーケットの拡大，経営資源の獲得をはじめとした樣々な側面においてグローバル化を余儀 なくされているが，国際資本移動の自由化に伴う M\&A 時代にあっては，あらゆる階層，プロセスにおいて従来 とは異なる技術移管あるいは集約スキームが要求されている．本講演では，ブランドの維持増強を視野に入れた 広義のデザインにおいて発生する技術課題を明らかにし，さらに内部競合を解消しつつ新たな価值を創造する方 法論としての設計の体系化あるいは Project Based Learning を中心とした教育の可能性検討について言及する.

\section{2. グローパル化の变谴と新たな技街鯟通}

第 2 次世界大戦後の日本の製造業と海外との関わりは繊維産業製品の輸出に始まり,その後 1970 年代に至る高 度経済成長期までは，鉄鋼，船舶が，臨海部の工場立地の利点を活かしつつ輸出の 1,2 位を占めていた. その後， 自動車を代表とする各種機械工業の興隆があり，続いて 1980 年代には, エレクトロニクス製品の輸出が盛んにな り，1995 年前後の一時期には自動車輸出を凌駕した. しかしながら一般的にモジュール化をべースとした電子機 器産業では，材料・デバイスあるいは基幹モジュール生産以外の主として製品組立プロセスの東アジア展開が急 速になされた．さらに近年は，化学製品の中国への輸出が活発化しており，その輸出シェアが伸長している，一 方，貿易摩擦，為替レート，グローバルマーケットの構造などの環境変化に呼応するように現地法人売上高も拡 大し，1993 年以降は日本からの輸出額を上回っている. 本講演では，現地法人の「技術」に関わる企業活動に焦 点を当てる，現地での生産活動は，自社あるいは現地合弁工場でのノックダウンに始まり，部品の現地調達率向

${ }^{* 1}$ 正員，ダイキン工業株式会社 テクノロジーイノベーションセンター推進室

E-mail: hiroyuki.itoh@daikin.co.jp 
上，現地市場向けの改装設計および日本への逆輸出など段階別に発展していくことが通例であり，この場合，「技 術」の首尾一貫性は，およそ維持されていたといえる，ところが，国際資本移動の自由化に伴い，企業の規模の 論理もグローバル化し，また市場開拓において，より一層の迅速性が要求されるところとなった，結果, 現地に 既存の同業他社の M\&A が活発化することとなり，いわゆる純粋な持株会社の形態をとらない限り，あらゆる階 層, プロセスにおいて従来とは異なる技術移管あるいは集約スキームの確立が急務となっている．具体的には， $\mathrm{CAD} / \mathrm{CAE}$ を初めとした ICT 環境, 地域法令を遵守した原価計算, 製品系列とプラットフォーム, 品質保証, さ らに集中開発と現地拠点開発の役割などについて合理性を有した統合化を進める必要がある. 中でも，上述すべ ての項目につながり，かつブランドの維持発展と密接に関係した上流デザインにおける価值創造プロセスについ ては，それらの重要要素からなるサブセットと捉えることで，今後の展望を与える役割を見出すことができる.

\section{3. 設計工学による眯䟄解決の試み}

\section{$3 \cdot 1$ 設計の体系化}

CAD 情報そのものは，図形のみならず部品情報まで瓦換性を保つための仕組みが IGES, STEP, Parasolid などに より整備されつつある. 一方で, 基本原理を共通に持ちながらも, ときに数十年間, 市場原理に内包される情報 交換なく独自の発達を遂げた製品群あるいはそれらを産み出寸設計システムを, 統合化ないしは経済性の成立す る範囲で共生させることは, 機械分野で一般的にいわれるところであるデザインの意図を全て図面に表現するこ との難しさの現代的課題である. より具体的には，イノベーションを企図する際の設計対象あるいは目的, CAD を媒介とした設計行為あるいはデザインレビューなどの開発プロセス管理方法などの違いである. これら, 雇用 慣行を含む地域経済に根ざした経路依存性の下で最適化されている実態を，例えば，アフォーダンスの集団的特 性と個別多様性といった設計工学の観点から解きほぐしていくことが，解決の糸口になるのではないかと考えら れる. (1),(2),(3)

\section{$3 \cdot 2$ Project Based Learning をはじめとする設計教育の可能性 ${ }^{(4)}$}

設計・開発を実践により習得することの重要性は言うまでもないが, CAD/CAE など身近なツールに搭載され ていない設計工学の手法を体系的に学ぶことの意義は小さくない. これが, Project Based Learning として結合さ れることにより, 相乗効果を産み出寸ことが実証されつつある. 本講演では, 報告者が, Stanford 大学, 大阪大 学で経験した事例を紹介しつつ, 産学の枠組みを残した発展形や産々を含むオープン協創の可能性について, さ らなる論点整理を試みる. また, 大規模事故に限らず, グローバルなビジネスモデルにおいても喫緊の課題とし て顕在化している巨大複雑系システムのデザインについても補足する.

\section{4. 結 語}

製造業のグローバル化と設計工学の関倸性について, 現在進行中の課題とその解決策を中心に紹介した. ネットワーク社会を前提とした巨大複雑系システムのデザインについて考察した.

\section{文献}

(1) 青木昌彦, “比較制度分析序説”, 講談社学術文庫, 2008

(2) D. A. ノーマン, ”誰のためのデザイン?”，新曜社，1992

(3) 佐々木正人, “アフォーダンス入門”, 講談社学術文庫, 2008

(4) 藤田喜久雄, “統合デザイン力教育プログラム”, 日本機械学会誌, Vol. 110, No. 1064(2007), pp. 523-524. 